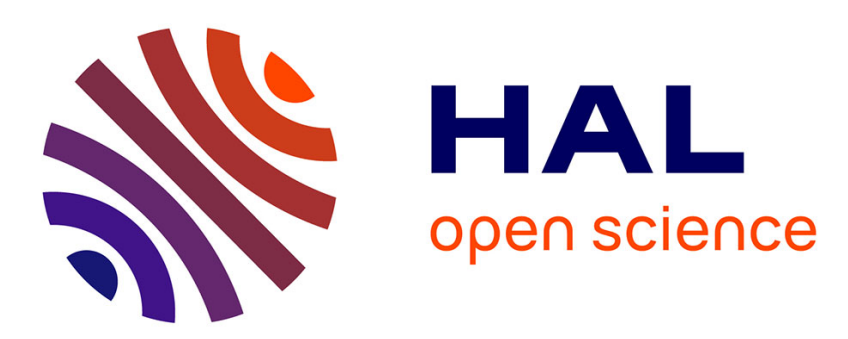

\title{
Reduction of [Cp*2Mo2O5] by mercaptopropionic acid in an aqueous medium. Isolation and characterization of \\ a dinuclear oxo- and 3-sulfido-proprionato(2-)-bridged molybdenum(IV) compound
}

Chiara Dinoi, Petr Prikhodchenko, Funda Demirhan, Jenny Gun, Ovadia Lev, Jean-Claude Daran, Rinaldo Poli

\section{To cite this version:}

Chiara Dinoi, Petr Prikhodchenko, Funda Demirhan, Jenny Gun, Ovadia Lev, et al.. Reduction of [Cp*2Mo2O5] by mercaptopropionic acid in an aqueous medium. Isolation and characterization of a dinuclear oxo- and 3-sulfido-proprionato(2-)-bridged molybdenum(IV) compound. Journal of Organometallic Chemistry, 2007, 692 (12), pp.2599-2605. 10.1016/j.jorganchem.2007.02.046 . hal03194589

\author{
HAL Id: hal-03194589 \\ https://hal.science/hal-03194589
}

Submitted on 9 Apr 2021

HAL is a multi-disciplinary open access archive for the deposit and dissemination of scientific research documents, whether they are published or not. The documents may come from teaching and research institutions in France or abroad, or from public or private research centers.
L'archive ouverte pluridisciplinaire HAL, est destinée au dépôt et à la diffusion de documents scientifiques de niveau recherche, publiés ou non, émanant des établissements d'enseignement et de recherche français ou étrangers, des laboratoires publics ou privés. 


\section{Reduction of $\left[\mathrm{Cp}_{2}^{*} \mathrm{Mo}_{2} \mathrm{O}_{5}\right]$ by mercaptopropionic acid in an aqueous}

\section{medium. Isolation and characterization of a dinuclear oxo- and 3-sulfido-}

\section{proprionato(2-)-bridged molybdenum(IV) compound}

Chiara Dinoi, ${ }^{\mathrm{a}}$ Petr Prikhodchenko, ${ }^{\mathrm{b}}$ Funda Demirhan, ${ }^{\mathrm{c}}$ Jenny Gun, ${ }^{\mathrm{b}}$ Ovadia Lev ${ }^{\mathrm{b}}$, Jean-

Claude Daran ${ }^{\mathrm{a}}$ and Rinaldo Poli*a

${ }^{a}$ Laboratoire de Chimie de Coordination, UPR CNRS 8241 liée par convention à l'Université Paul Sabatier et à l'Institut National Polytechnique de Toulouse, 205 Route de Narbonne,

31077 Toulouse Cedex, France.

${ }^{\mathrm{b}}$ Div. of Environmental Sciences, Fredy and Nadine Hermann School of Applied Science, The Hebrew University of Jerusalem, Jerusalem, Israel

${ }^{\mathrm{c} C e l a l}$ Bayar University, Faculty of Sciences \& Liberal Arts, Department of Chemistry, 45030, Muradiye-Manisa, Turkey

Proofs to:

Rinaldo Poli

Tel: $+33-561333173$

Fax: +33-561553003

E-mail: poli@1cc-toulouse.fr 


\section{Summary}

Reaction of $\mathrm{Cp}_{2}{ }_{2} \mathrm{Mo}_{2} \mathrm{O}_{5}$ with $\mathrm{HSCH}_{2} \mathrm{CH}_{2} \mathrm{COOH}$ in acidic (by $\mathrm{CF}_{3} \mathrm{COOH}$ ) 50:50 MeOH-H${ }_{2} \mathrm{O}$ solvent at room temperature yields compound $\mathrm{Cp}^{*}{ }_{2} \mathrm{Mo}_{2}(\mu-\mathrm{O})\left(\mu-\mathrm{SCH}_{2} \mathrm{CH}_{2} \mathrm{CO}_{2}\right)_{2}$, a dinuclear diamagnetic $\mathrm{Mo}^{\mathrm{IV}}$ compound with a two-leg-sharing bis(four-legged piano stool) structure and a Mo-Mo distance of 2.6833(6) А. A reaction monitoring by ESI MS shows the formation of an intermediate 18 mass units heavier, interpreted as a dihydroxo analogue. Electrochemistry shows a reversible, $\mathrm{pH}$ independent oxidation process and an irreversible, $\mathrm{pH}$-dependent reduction process. Contrary to a recently published analogous reaction with the closely related $\mathrm{HSCH}_{2} \mathrm{COOH}$ substrate, this process does not lead to C-S bond cleavage.

\section{Keywords}

Molybdenum, aqueous organometallic chemistry, alkylsulfido ligands, carboxylato ligands, pentamethylcyclopentadienyl ligands. 


\section{Introduction}

Aqueous organometallic chemistry is attracting growing interest because of its "green" impact [1-3] and because of its potential in catalytic [4, 5] and biomedical applications [6]. Although this area is widely explored for low-valent systems, usually upon appending hydrophilic functionalities to the ligand periphery in order to increase solubility in an aqueous environment [7-9], studies of high oxidation organometallics are still rather scarce [10]. For redox-active metals, these studies are particularly interesting as they may open the way to electrocatalytic applications [10].

In a recent contribution [11], we have reported the result of the interaction between compound $\left[\mathrm{Cp}_{2}^{*} \mathrm{Mo}_{2} \mathrm{O}_{5}\right]$ and mercaptoacetic (or thioglycolic) acid, $\mathrm{HSCH}_{2} \mathrm{COOH}$, which resulted in the isolation and characterization of the dinuclear $\mathrm{Mo}^{\mathrm{IV}}$ product $\left[\mathrm{Cp}^{*}{ }_{2} \mathrm{Mo}_{2}(\mu-\mathrm{S})(\mu-\right.$ $\left.\mathrm{SCH}_{2} \mathrm{COO}\right)_{2}$. In this reaction, the mercaptoacetic acid exerts three simultaneous functions: reducing agent, ligand, and substrate for the reductive cleavage of the S-C bond (leading to the incorporation of the sulphur atom in the isolated product as a bridging sulfido ligand). This phenomenon, which is common to other Mo-mediated C-S bond cleavage reactions [1217], mimics a step of the hydrodesulfurization process, which is in fact typically catalyzed by molybdenum-sulfur compounds [18-21]. We were interested in probing the generality of this reaction and proceeded to explore the reaction with mercaptopropionic acid, $\mathrm{HSCH}_{2} \mathrm{CH}_{2} \mathrm{COOH}$, which contains an additional methylene unit between the acid and the mercapto functions relative to mercaptoacetic acid. The outcome of this reaction, which is unexpectedly different from that of the lighter analogue, is reported and discussed in this contribution.

\section{Experimental Section}


General procedures. All preparations and manipulations were carried out with Schlenk techniques under an oxygen-free argon atmosphere. All glassware was oven-dried at $120^{\circ} \mathrm{C}$. Solvents were dried by standard procedures and distilled under dinitrogen prior to use. ${ }^{1} \mathrm{H}$ NMR spectra were recorded on a Bruker AM 250, operating at $250 \mathrm{MHz}$. Chemical shifts are expressed in ppm downfield from $\mathrm{Me}_{4} \mathrm{Si}$. Coupling constants are given in Hertz. The 2DCOSY spectrum were recorded on a Bruker Avance 500, operating at $500 \mathrm{MHz}$. Mass spectra were recorded with a Finnigan (San Francisco, USA) LCQ quadrupole ion-trap mass spectrometer equipped with an electrospray-ionization (ESI) interface. The ESI was operated in the positive-ion mode with a spray voltage of $4.0 \mathrm{kV}$, a capillary voltage of $5.5 \mathrm{~V}$, and a source temperature of $100{ }^{\circ} \mathrm{C}$. Mass spectra were obtained by scanning the mass analyzer from $\mathrm{m} / z, 100$ to 2000 with a total of 3 microscans. The maximum injection time into the ion trap was $25 \mathrm{~ms}$. The analyzer was operated at a background pressure of $2 \cdot 10^{-5}$ Torr. The compounds were isolated in the ion trap with isolation width of $15 \mathrm{~m} / z$ units and were activated by using increased collision energy to obtain the sequential product-ion fragmentation by collision-energy-dissociation [22, 23]. The starting compound, $\left[\mathrm{Cp}_{2}{ }_{2} \mathrm{Mo}_{2} \mathrm{O}_{5}\right]$, was prepared as described in the literature [24]. The 3-mercaptopropionic acid (99\%, ACROS) and the trifluoroacetic acid (99\%, ACROS) were used as received. Cyclic voltammograms were recorded with an EG\&G 362 potentiostat connected to a Macintosh computer through MacLab hardware/sofware. The electrochemical cell was fitted with an $\mathrm{Ag}-\mathrm{AgCl}(\mathrm{KCl}$ sat$)$ reference electrode, a platinum disk working electrode for aprotic solvents or glassy carbon disk electrode for $\mathrm{H}_{2} \mathrm{O}-\mathrm{MeOH}$ solution, and a platinum wire counterelectrode. $\left[\mathrm{Bu}_{4} \mathrm{~N}\right] \mathrm{PF}_{6}\left(\mathrm{ca} .0 .1 \mathrm{M}\right.$ ) was used as supporting electrolyte in $\mathrm{CH}_{2} \mathrm{Cl}_{2}$ whereas $\mathrm{NH}_{4} \mathrm{Ac}(0.1 \mathrm{M})$ was used as a supporting electrolyte in addition to buffer solutions at different $\mathrm{pH}$ in $\mathrm{MeOH}-\mathrm{H}_{2} \mathrm{O}$. All potentials are reported relative to the ferrocene standard, which was 
added to each solution and measured at the end of the experiments. EPR measurements were carried out at the X-band microwave frequency on a Bruker ESP300 spectrometer. The spectrometer frequency was calibrated with diphenylpicrylhydrazyl (DPPH, g $=2.0037$ ).

Preparation of $\left[\mathbf{C p}^{*} \mathrm{Mo}\left(\mu-\mathrm{SCH}_{2} \mathrm{CH}_{2} \mathbf{C O O}\right)\right]_{2}(\mu-\mathbf{O}) . \mathrm{HSCH}_{2} \mathrm{CH}_{2} \mathrm{COOH}(0.392 \mathrm{~g}, 3.69$ mmol) and 9 drops of $\mathrm{CF}_{3} \mathrm{COOH}$ were added to a solution of $\mathrm{Cp}_{2}{ }_{2} \mathrm{Mo}_{2} \mathrm{O}_{5}(0.200 \mathrm{~g}, 0.369$ mmol) in $\mathrm{MeOH}: \mathrm{H}_{2} \mathrm{O}(1: 1,5 \mathrm{ml})$, resulting in a color change from yellow to red-brown. After $3 \mathrm{~h}$ of stirring, all solvents were removed in vacuum and the oily residue was washed with $2 \mathrm{x}$ $5 \mathrm{ml}$ of oxygen-free distilled water and with $2 \times 5 \mathrm{ml}$ of pentane. The resulting red-brown residue was extracted with THF, followed by addition of pentane to yield a brown precipitate which was filtered and isolated $\left(0.127 \mathrm{~g}, 38 \%\right.$ yield). The product is soluble in $\mathrm{CH}_{2} \mathrm{Cl}_{2}$ and THF, insoluble in $\mathrm{Et}_{2} \mathrm{O}$ and saturated hydrocarbons. The NMR of the isolated product showed only the presence of the title compound, but the presence of a paramagnetic impurity, which could not be crystallized in pure form, was revealed by EPR spectroscopy in $\mathrm{CDCl}_{3}$ ( $\mathrm{g}$ $\left.=1.97, \mathrm{a}_{\mathrm{Mo}}=41.6 \mathrm{G}\right)$. The ${ }^{1} \mathrm{H}$ NMR spectrum $\left(\mathrm{CDCl}_{3}\right)$ revealed extensive overlap between the methylene protons of the ligand and those in a co-crystallized $\mathrm{HOOCCH}_{2} \mathrm{CH}_{2} \mathrm{SSCH}_{2} \mathrm{CH}_{2} \mathrm{COOH}$ molecule (also revealed by the X-ray analysis on a single crystal). The assignment was aided by a 2D-COSY analysis (see Results section). For the dinuclear Mo complex: $\delta 2.96\left(\mathrm{~m}, 1 \mathrm{H}, \mathrm{H}_{\mathrm{a}}\right), 2.65\left(\mathrm{~m}, 1 \mathrm{H}, \mathrm{H}_{\mathrm{b}}\right), 2.59\left(\mathrm{~m}, 1 \mathrm{H}, \mathrm{H}_{\mathrm{c}}\right), 1.93(\mathrm{~s}, 15 \mathrm{H}$, $\left.\mathrm{Cp}^{*}\right), 1.87\left(\mathrm{~m}, 1 \mathrm{H}, \mathrm{H}_{\mathrm{d}}\right)$. For the disulfide by-product: $\delta 2.99(\mathrm{t}, \mathrm{J}=7.1 \mathrm{~Hz}), 2.81(\mathrm{t}, \mathrm{J}=7.2$ Hz). Subsequent recrystallizations of the crude material did not completely remove the paramagnetic impurity (as shown by EPR spectroscopy), a possible reason for the imperfect analytical results: calculated for $\mathrm{C}_{32} \mathrm{H}_{48} \mathrm{Mo}_{2} \mathrm{O}_{9} \mathrm{~S}_{4}$ (896.86): C, 42.8; H, 5.4. Found: C, 42.1; H, 4.8. A single crystal for the X-ray analysis was obtained by diffusion of a pentane layer into a brown $\mathrm{CH}_{2} \mathrm{Cl}_{2}$ solution of the crude reaction product at room temperature. 
X-ray diffraction study. A single crystal of the compound was mounted under inert perfluoropolyether on the tip of glass fibre and cooled in the cryostream of the OxfordDiffraction XCALIBUR CCD diffractometer. Data were collected using the monochromatic MoK $\alpha$ radiation $(\lambda=0.71073)$. The structure was solved by direct methods (SIR97) [25] and refined by least-squares procedures on $F^{2}$ using SHELXL-97 [26]. All H atoms attached to carbon and oxygen $(\mathrm{OH})$ were introduced in calculation in idealised positions and treated as riding on their parent atoms. The drawing of the molecules was realised with the help of ORTEP32 [27]. Crystal data and refinement parameters are shown in Table 1 and selected bond distances and bond angles in Erreur! Source du renvoi introuvable.. Crystallographic data (excluding structure factors) have been deposited with the Cambridge Crystallographic Data Centre as supplementary publication no. CCDC 632621. Copies of the data can be obtained free of charge on application to the Director, CCDC, 12 Union Road, Cambridge CB2 1EZ, UK (fax: (+44) 1223-336-033; e-mail: deposit@ ccdc.cam.ac.uk).

Table 1. Selected crystallographic and refinement parameters for compound $\left[\mathrm{Cp}^{*}{ }_{2} \mathrm{Mo}_{2}(\mu-\right.$ $\left.\mathrm{O})\left(\mu-\mathrm{SCH}_{2} \mathrm{CH}_{2} \mathrm{CO}_{2}\right)_{2}\right] \cdot\left(\mathrm{HO}_{2} \mathrm{CCH}_{2} \mathrm{CH}_{2} \mathrm{SSCH}_{2} \mathrm{CH}_{2} \mathrm{COOH}\right)$.

Empirical formula

Formula weight

Temperature

Wavelength

Crystal system

Space group

Unit cell dimensions

Volume

$\mathrm{Z}$

Density (calculated)

Absorption coefficient

$\mathrm{F}(000)$

Crystal size
$\mathrm{C}_{32} \mathrm{H}_{48} \mathrm{Mo}_{2} \mathrm{O}_{9} \mathrm{~S}_{4}$

896.82

180(2) K

$0.71073 \AA$

Triclinic

$\mathrm{P}-1$

$\mathrm{a}=8.6819(9) \AA$ $\alpha=85.526(7)^{\circ}$.

$\mathrm{b}=14.2934(12) \AA$ $\beta=73.494(8)^{\circ}$. $\mathrm{c}=15.8121(14) \AA$ 1874.6(3) $\AA^{3}$ $\gamma=86.910(7)^{\circ}$.

$1.589 \mathrm{Mg} / \mathrm{m}^{3}$

$0.941 \mathrm{~mm}^{-1}$ 920

$0.42 \times 0.11 \times 0.063 \mathrm{~mm}^{3}$ 
Theta range for data collection

Index ranges

Reflections collected

Independent reflections

Completeness to theta $=30.40^{\circ}$

Absorption correction

Max. and min. transmission

Refinement method

Data / restraints / parameters

${ }^{\mathrm{c}}$ Goodness-of-fit on $\mathrm{F}^{2}$

Final $\mathrm{R}$ indices [I>2sigma(I)]

$\mathrm{R}$ indices (all data)

Largest diff. peak and hole

\subsection{5 to $30.44^{\circ}$}

$-12<=\mathrm{h}<=12,-20<=\mathrm{k}<=20,-22<=\mathrm{l}<=19$

19719

11259 [R(int) $=0.0477]$

$98.1 \%$

Semi-empirical from equivalents

0.9149 and 0.7873

Full-matrix least-squares on $\mathrm{F}^{2}$

11259 / 0 / 435

0.931

${ }^{\mathrm{a}} \mathrm{R} 1=0.0464,{ }^{\mathrm{b}} \mathrm{wR} 2=0.1016$

${ }^{\mathrm{a}} \mathrm{R} 1=0.0948,{ }^{\mathrm{b}} \mathrm{wR} 2=0.1325$

1.076 and -1.228 e. $\AA^{-3}$

Table 2. Selected bond distances $(\AA)$ and angles $\left(^{\circ}\right)$ for compound $\left[\mathrm{Cp}^{*}{ }_{2} \mathrm{Mo}_{2}(\mu-\mathrm{O})(\mu-\right.$ $\left.\left.\mathrm{SCH}_{2} \mathrm{CH}_{2} \mathrm{CO}_{2}\right)_{2}\right] \cdot\left(\mathrm{HO}_{2} \mathrm{CCH}_{2} \mathrm{CH}_{2} \mathrm{SSCH}_{2} \mathrm{CH}_{2} \mathrm{COOH}\right)^{a}{ }^{a}$

\begin{tabular}{|ll|ll|}
\hline $\mathrm{Mo}(1)-\mathrm{O}(1)$ & $1.926(3)$ & $\mathrm{Mo}(2)-\mathrm{O}(1)$ & $1.933(3)$ \\
\hline $\mathrm{Mo}(1)-\mathrm{CG} 1$ & $2.0205(4)$ & $\mathrm{Mo}(2)-\mathrm{CG} 2$ & $2.0222(4)$ \\
\hline $\mathrm{Mo}(1)-\mathrm{O}(61)$ & $2.056(3)$ & $\mathrm{Mo}(2)-\mathrm{O}(31)$ & $2.078(3)$ \\
\hline $\mathrm{Mo}(1)-\mathrm{S}(1)$ & $2.4506(11)$ & $\mathrm{Mo}(2)-\mathrm{S}(1)$ & $2.4545(11)$ \\
\hline $\mathrm{Mo}(1)-\mathrm{S}(2)$ & $2.4633(11)$ & $\mathrm{Mo}(2)-\mathrm{S}(2)$ & $2.4439(11)$ \\
\hline $\mathrm{Mo}(1)-\mathrm{Mo}(2)$ & $2.6833(6)$ & & \\
\hline
\end{tabular}

\begin{tabular}{|c|c|c|c|}
\hline $\mathrm{O}(1)-\mathrm{Mo}(1)-\mathrm{CG} 1$ & $109.68(9)$ & $\mathrm{O}(1)-\mathrm{Mo}(2)-\mathrm{CG} 2$ & $109.22(9)$ \\
\hline $\mathrm{O}(1)-\mathrm{Mo}(1)-\mathrm{S}(1)$ & $72.39(9)$ & $\mathrm{O}(1)-\mathrm{Mo}(2)-\mathrm{S}(2)$ & $72.42(9)$ \\
\hline CG1-Mo(1)-S(1) & $124.79(3)$ & CG2-Mo(2)-S(2) & $124.60(3)$ \\
\hline $\mathrm{O}(61)-\mathrm{Mo}(1)-\mathrm{S}(1)$ & $87.34(9)$ & $\mathrm{O}(31)-\mathrm{Mo}(2)-\mathrm{S}(2)$ & $86.62(8)$ \\
\hline $\mathrm{O}(1)-\mathrm{Mo}(1)-\mathrm{S}(2)$ & $72.06(9)$ & $\mathrm{O}(1)-\mathrm{Mo}(2)-\mathrm{S}(1)$ & $72.20(9)$ \\
\hline CG1-Mo(1)-S(2) & $121.07(3)$ & CG2-Mo(2)-S(1) & $120.57(3)$ \\
\hline $\mathrm{O}(61)-\mathrm{Mo}(1)-\mathrm{S}(2)$ & $86.60(8)$ & $\mathrm{O}(31)-\mathrm{Mo}(2)-\mathrm{S}(1)$ & $86.77(8)$ \\
\hline $\mathrm{S}(1)-\mathrm{Mo}(1)-\mathrm{S}(2)$ & $112.04(4)$ & $\mathrm{S}(2)-\mathrm{Mo}(2)-\mathrm{S}(1)$ & $112.58(4)$ \\
\hline CG1-Mo(1)-Mo(2) & $155.67(2)$ & CG2-Mo(2)-Mo(1) & $154.99(2)$ \\
\hline $\mathrm{O}(61)-\mathrm{Mo}(1)-\mathrm{Mo}(2)$ & $95.41(8)$ & $\mathrm{O}(31)-\mathrm{Mo}(2)-\mathrm{Mo}(1)$ & $94.98(8)$ \\
\hline $\mathrm{O}(1)-\mathrm{Mo}(1)-\mathrm{O}(61)$ & $141.46(12)$ & $\mathrm{O}(1)-\mathrm{Mo}(2)-\mathrm{O}(31)$ & $140.83(12)$ \\
\hline CG1-Mo(1)-O(61) & $108.81(8)$ & $\mathrm{CG} 2-\mathrm{Mo}(2)-\mathrm{O}(31)$ & $109.92(8)$ \\
\hline $\operatorname{Mo}(1)-S(1)-\operatorname{Mo}(2)$ & $66.33(3)$ & $\operatorname{Mo}(2)-S(2)-\operatorname{Mo}(1)$ & $66.29(3)$ \\
\hline $\operatorname{Mo}(1)-\mathrm{O}(1)-\mathrm{Mo}(2)$ & $88.09(12)$ & & \\
\hline
\end{tabular}


${ }^{\mathrm{a}} \mathrm{CG} 1$ and $\mathrm{CG} 2$ are the centers of gravity of the $\mathrm{Cp} \mathrm{p}^{*}$ rings (calculated on the basis of atoms C11-C15 and C21-C35, respectively).

\section{Results and Discussion}

The reaction between $\mathrm{Cp}_{2}{ }_{2} \mathrm{Mo}_{2} \mathrm{O}_{5}$ and $\mathrm{HSCH}_{2} \mathrm{CH}_{2} \mathrm{COOH}$ qualitatively appeared to follow the same course as the related, previously described reaction with the related substrate $\mathrm{HSCH}_{2} \mathrm{COOH}$ [11], under identical experimental conditions (room temperature in a 1:1 $\mathrm{H}_{2} \mathrm{O}$ $\mathrm{MeOH}$ mixture, acidified with $\mathrm{CF}_{3} \mathrm{COOH}$ ), as suggested by the colour change and the ${ }^{1} \mathrm{H}$ NMR spectrum of the final product. However, crystallization of the product and determination of its molecular structure by single crystal X-ray diffraction yielded a surprising result: the product corresponds to the formulation $\left[\mathrm{Cp}_{2}^{*} \mathrm{Mo}_{2}(\mu-\mathrm{O})(\mu-\right.$ $\left.\left.\mathrm{SCH}_{2} \mathrm{CH}_{2} \mathrm{COO}\right)_{2}\right]$ and therefore features an oxo bridge, whereas the analogous reaction with the mercaptoacetic acid yielded the sulphur bridged derivative, $\left[\mathrm{Cp}^{*}{ }_{2} \mathrm{Mo}_{2}(\mu-\mathrm{S})(\mu-\right.$ $\left.\left.\mathrm{SCH}_{2} \mathrm{COO}\right)_{2}\right][11]$.

A reaction monitoring by electrospray mass spectrometric revealed that, in fact, the primary reaction product has a molecular mass 18 units greater $(\mathrm{M} / \mathrm{z}=704.7)$. The isotopic envelope corresponding to this intermediate decreases as the reaction progresses, accompanied by the increase of the product isotopic envelope $(\mathrm{m} / \mathrm{z}=687.0)$, as shown in Figure S1 (Supporting Information). The observed peaks have one mass unit greater than the neutral solution species, because of the addition of a proton from the medium. Thus, the final envelope corresponds to species $\left[\mathrm{Cp}^{*}{ }_{2} \mathrm{Mo}_{2}(\mu-\mathrm{O})\left(\mu-\mathrm{SCH}_{2} \mathrm{CH}_{2} \mathrm{COO}\right)_{2}+\mathrm{H}^{+}\right]$. The conversion of the intermediate into the final product is likely an intramolecular process, because an MS/MS investigation (collision induced decay of the intermediate with maximum at $\mathrm{m} / \mathrm{z}=705$ ) shows that the same transformation also occurs cleanly in the gas phase. An MS/MS study of the isolated product peaks (Figure 1) reveals various decay patterns, the major ones 
corresponding to a single and a double loss of 72 mass units. This is easily interpreted as the loss of $\mathrm{CH}_{2} \mathrm{CH}_{2} \mathrm{CO}_{2}$ units from the mercaptopropionato(2-) ligand, leaving a sulfido bridge on the dinuclear complex. MS/MS/MS on the peak resulting from the first $\mathrm{CH}_{2} \mathrm{CH}_{2} \mathrm{CO}_{2}$ loss (at $\mathrm{m} / \mathrm{z}$ 615), also shown in Figure 1, mostly yields the second $\mathrm{CH}_{2} \mathrm{CH}_{2} \mathrm{CO}_{2}$ expulsion product. The presence of two envelopes $16 \mathrm{~m} / \mathrm{z}$ units lighter than the above fragments (at $\mathrm{m} / \mathrm{z} 599$ and 529, respectively) is unlikely due to subsequent oxygen atom expulsion. Rather, these peaks could correspond to minor fragmentation pathways involving the elimination of $\mathrm{SCH}_{2} \mathrm{CH}_{2} \mathrm{CO}$ (m/z 88), thereby leaving an oxo bridge on the dinuclear complex.

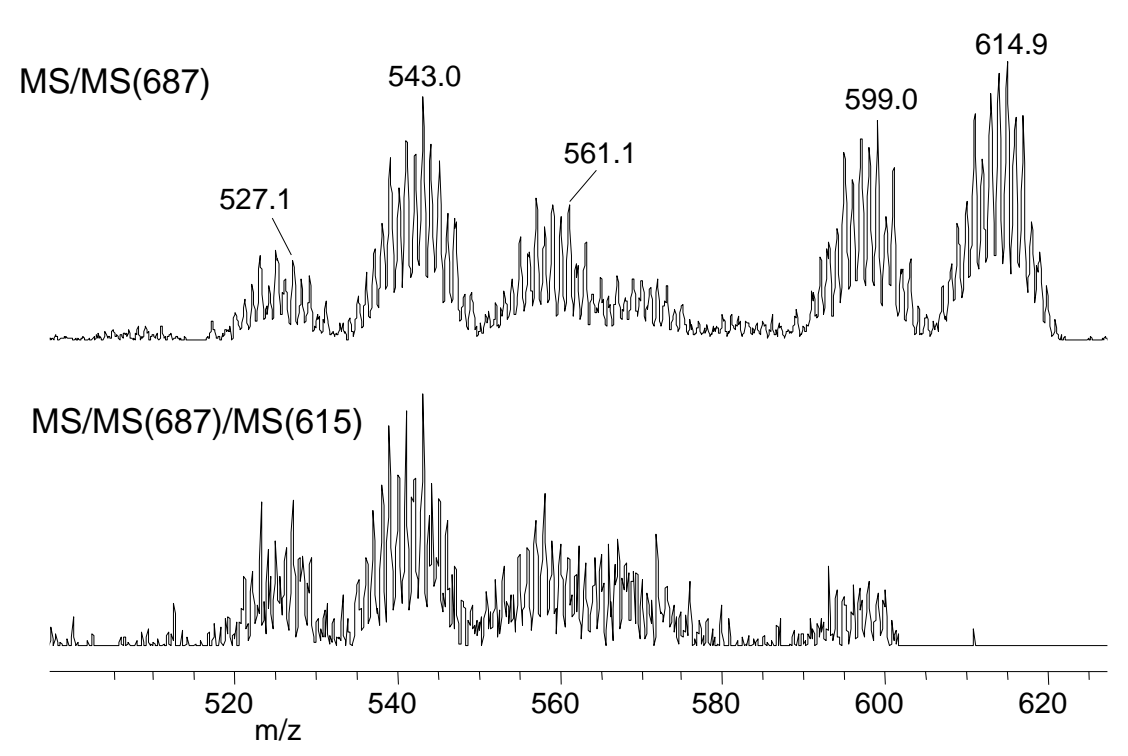

Figure 1. $M S^{n}$ studies of the fragmentation pattern of compound $\left[\mathrm{Cp}^{*} 2 \mathrm{Mo} 2(\mu-\mathrm{O})(\mu-\right.$ $\left.\left.\mathrm{SCH}_{2} \mathrm{CH}_{2} \mathrm{COO}\right)_{2}\right]+\mathrm{H}^{+}$(peak at $\mathrm{m} / \mathrm{z}=687$ ). Relative collision energy at every step is $15 \%$.

The fragment of mass 18 lost during the transformation of intermediate to product must of course correspond to a water molecule. Thus, the likely stoichiometry of the intermediate is $\left[\mathrm{Cp}^{*}{ }_{2} \mathrm{Mo}_{2}(\mathrm{OH})_{2}\left(\mathrm{SCH}_{2} \mathrm{CH}_{2} \mathrm{COO}\right)_{2}\right]$. This structural type is precedented, examples being $\mathrm{Cp}_{2}{ }_{2} \mathrm{Mo}_{2} \mathrm{Cl}_{2}(\mu-\mathrm{Cl})(\mu-\mathrm{O})\left(\mu-\mathrm{O}_{2} \mathrm{COH}\right)[28]$ and $\mathrm{Cp}_{2}{ }_{2} \mathrm{Mo}_{2} \mathrm{X}_{4}(\mu-\mathrm{X})_{2}(\mathrm{X}=\mathrm{Cl}, \mathrm{Br})[29,30]$. It probably involves alkylsulfido bridges rather than hydroxo bridges, since the former groups 
are generally better bridging ligands. The necessary rearrangement leading from two hydroxo ligand to an oxo bridge with loss of $\mathrm{H}_{2} \mathrm{O}$ would account for the relatively slow process. If this is true, the stoichiometry of the first reaction leading to the intermediate follows Equation 1. In this reaction, 4 equivalents of the mercaptoacid perform the reduction process, providing 4 protons and 4 electrons. The latter reduce the two Mo centers from VI to IV. Two additional mercaptoacid molecules coordinate the metal centers, stabilizing the dinuclear product and contribute 4 additional protons. Six of the eight protons are used to liberate 3 oxo ligands as water molecules, the two residual ones converting the remaining two oxo ligands to $\mathrm{OH}$. The reaction then continues as shown in Equation 2.

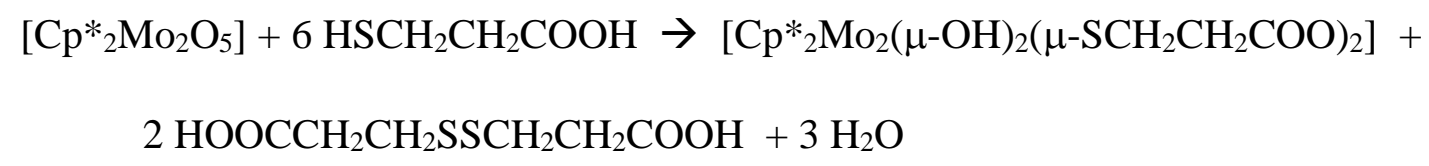

\section{Equation 1}

$$
\left[\mathrm{Cp}_{2}{ }_{2} \mathrm{Mo}_{2}(\mu-\mathrm{OH})_{2}\left(\mu-\mathrm{SCH}_{2} \mathrm{CH}_{2} \mathrm{COO}\right)_{2}\right] \rightarrow\left[\mathrm{Cp}_{2}{ }_{2} \mathrm{Mo}_{2}(\mu-\mathrm{O})\left(\mu-\mathrm{SCH}_{2} \mathrm{CH}_{2} \mathrm{COO}\right)_{2}\right]+\mathrm{H}_{2} \mathrm{O}
$$

\section{Equation 2}

As was the case for the related mercaptoacetic acid reaction, the product obtained with the mercaptopropionic acid co-crystallized together with a molecule of the disulfide byproduct, thereby providing direct evidence for its formation (Equation 1). A view of the dinuclear Mo compound is shown in Figure 2. The coordination geometry around each Mo center can best be described as a four-legged piano stool, the four legs being defined by the three bridging atoms (two $\mathrm{S}$ and one $\mathrm{O}$ ) and by a terminally bonded second $\mathrm{O}$ atom from the carboxylate function. It is a member of the relatively large family of triply-bridged dinuclear $\left(\mathrm{CpMo}^{\mathrm{IV}}\right)$ compounds, other members of which are $\mathrm{Cp}^{*}{ }_{2} \mathrm{Mo}_{2} \mathrm{Br}_{2}(\mu-\mathrm{Br})(\mu-\mathrm{O})(\mu-\mathrm{SMe})[31]$, 
$\mathrm{Cp}^{*}{ }_{2} \mathrm{Mo}_{2} \mathrm{Cl}_{2}(\mu-\mathrm{O})(\mu-\mathrm{Cl})_{2}$ [28], and $\left[\mathrm{Cp}^{*}{ }_{2} \mathrm{Mo}_{2} \mathrm{Cl}_{2}(\mu-\mathrm{Cl})_{3}\right]^{+}$[32]. The overall geometry is identical to that recently described for the mercaptoacetic acid product [11], the bridging sulphur atom in the latter being replaced by a bridging oxygen atom. The Mo-Mo distance (see Erreur ! Source du renvoi introuvable.) is over $0.1 \AA$ shorter than in the $\mathrm{Cp}_{2}{ }_{2} \mathrm{Mo}_{2}(\mu-$ $\mathrm{S})\left(\mu-\mathrm{SCH}_{2} \mathrm{COO}\right)_{2}$ analogue [2.7929(4) $\AA$ ] [11]. This is certainly related to the smaller size of the bridging $\mathrm{O}$ atom relative to $\mathrm{S}$, because the distances from the metal to the bridging thiolato $\mathrm{S}$ atoms are identical in the two compounds (averages of 2.453(8) $\AA$ and 2.452(15) $\AA$ for the O- and S-bridged compounds). The average distances to the $\mathrm{Cp}^{*}$ center of gravity [2.021(1) vs. 2.013(5) $\AA$ ], and to the terminal carboxylate O donor [2.067(11) vs. 2.090(4) $\AA$ ] are also very close to those in the thioglycolate analogue. In terms of bond angles, there is an obvious difference at the level of the different bridging atom [Mo-O-Mo, 88.09(12) ${ }^{\circ}$; vs. Mo-S-Mo, 74.37(2)]. On the other hand, the average Mo-S-Mo angles involving the thiolato ligand are slightly smaller in the oxo-bridged product reported here $\left[66.30(3)^{\circ}\right.$, vs. $69.4(4)^{\circ}$ is the $\mathrm{S}$ bridged product]. This is certainly a secondary effect, related to the shorter Mo-Mo distance. The other geometric parameters are sensibly identical in the two compounds. As already found for the $\left[\mathrm{Cp}_{2}{ }_{2} \mathrm{Mo}_{2}(\mu-\mathrm{S})\left(\mu-\mathrm{SCH}_{2} \mathrm{COO}\right)_{2}\right]$ structure [11], the dinuclear $\left[\mathrm{Cp}_{2}{ }_{2} \mathrm{Mo}_{2}(\mu-\mathrm{O})(\mu-\right.$ $\left.\mathrm{SCH}_{2} \mathrm{CH}_{2} \mathrm{COO}\right)_{2}$ ] product establishes $\mathrm{H}$-bonds with the disulfide by-product. They yield a pseudo dimer by associating two dinuclear complexes and two disulfide by-products, with a graph-set motif of $\mathrm{R}_{4}{ }^{4}(42)[33,34]$, as highlighted in Figure 3. Relevant metric parameters are collected in Table 3.

Table 3. Relevant hydrogen bonding parameters for the structured of compound $\left[\mathrm{Cp}_{2}{ }_{2} \mathrm{Mo}_{2}(\mu-\mathrm{O})\left(\mu-\mathrm{SCH}_{2} \mathrm{CH}_{2} \mathrm{CO}_{2}\right)_{2}\right] \cdot\left(\mathrm{HO}_{2} \mathrm{CCH}_{2} \mathrm{CH}_{2} \mathrm{SSCH}_{2} \mathrm{CH}_{2} \mathrm{COOH}\right){ }^{\mathrm{a}}$

\begin{tabular}{|c|c|c|c|c|}
\hline & $\mathrm{O}-\mathrm{H}(\AA)$ & $\mathrm{H} \ldots \mathrm{O}(\AA)$ & $\mathrm{O} \ldots \mathrm{O}(\AA)$ & $\mathrm{O}-\mathrm{H} \ldots \mathrm{H}\left({ }^{\circ}\right)$ \\
\hline $\mathrm{O} 432-\mathrm{H} 432 \ldots \mathrm{O} 62$ & 0.84 & 1.82 & $2.605(6)$ & 154 \\
\hline $\mathrm{O} 332-\mathrm{H} 332 \ldots \mathrm{O} 32^{\mathrm{i}}$ & 0.84 & 1.78 & $2.587(5)$ & 160 \\
\hline
\end{tabular}

aSymmetry code: (i) -x, -y, -z+1. 


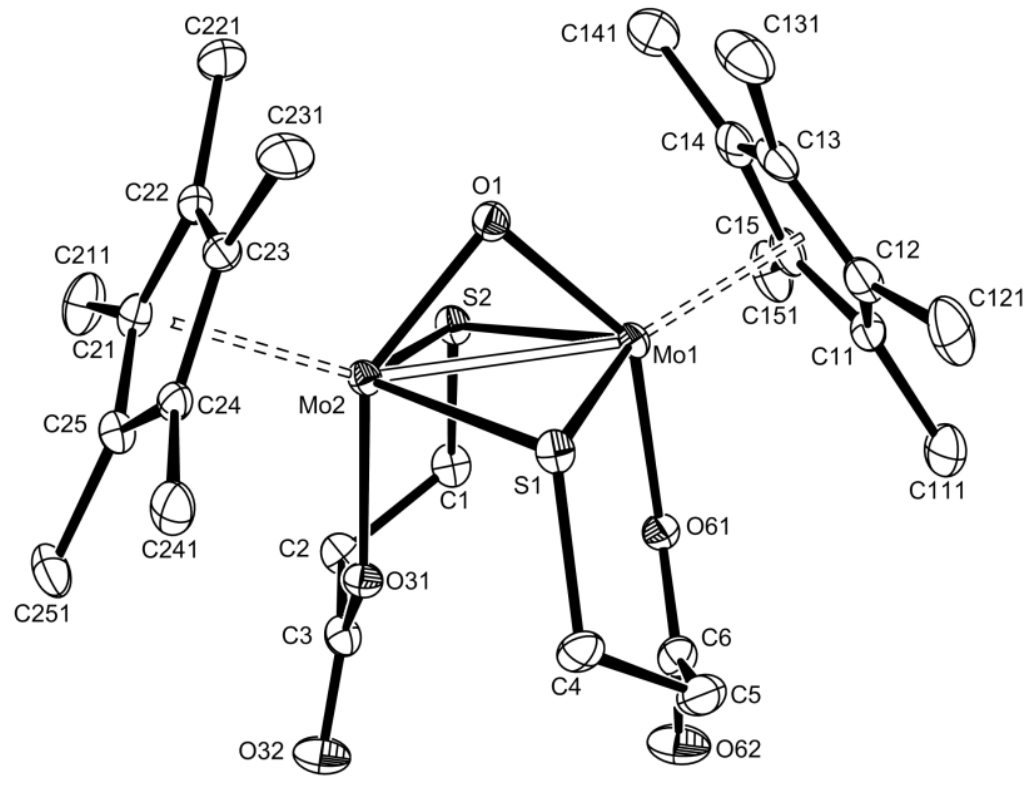

Figure 2. ORTEP view of compound $\left[\mathrm{Cp}^{*}{ }_{2} \mathrm{Mo}_{2}(\mu-\mathrm{O})\left(\mu-\mathrm{SCH}_{2} \mathrm{CH}_{2} \mathrm{COO}\right)_{2}\right]$. Hydrogen atoms have been omitted for clarity

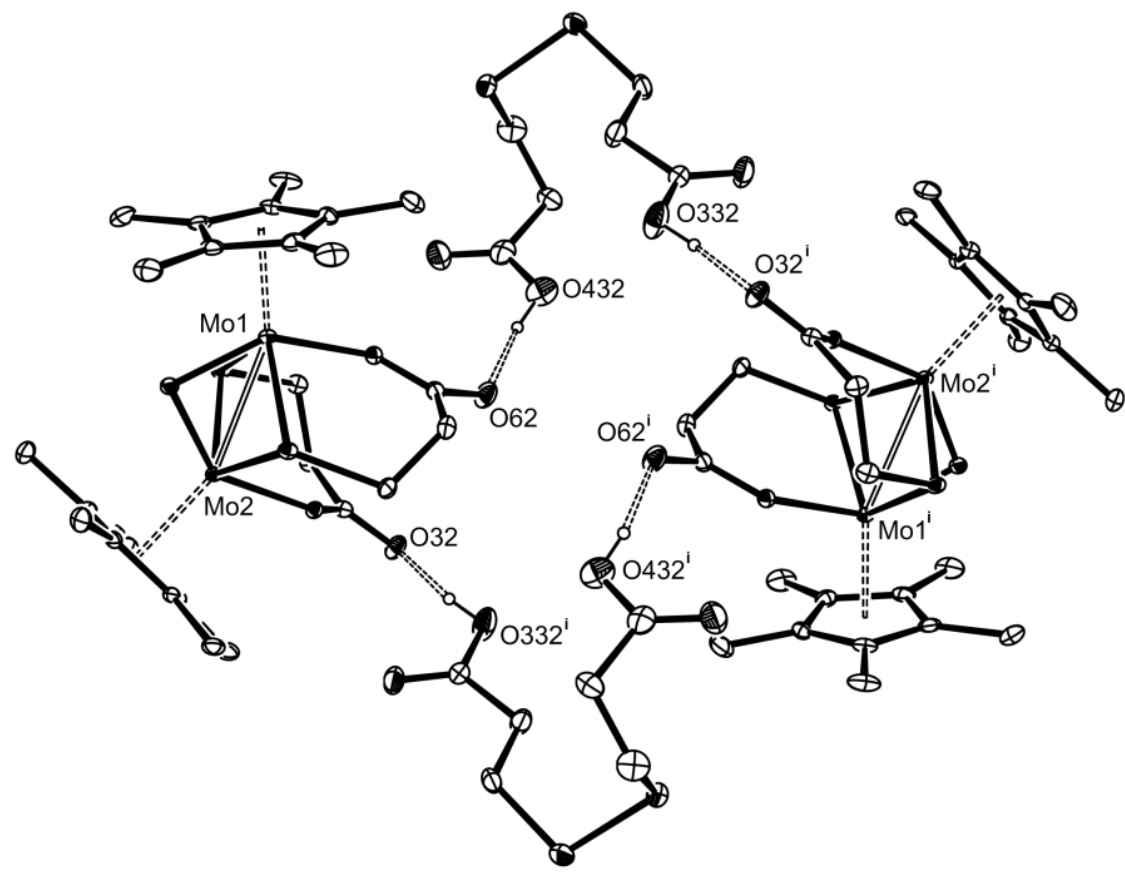

Figure 3. ORTEP view highlighting the $\mathrm{R}_{4}^{4}(42)$ graph-set motif formed by $\mathrm{O}-\mathrm{H} \cdots \mathrm{O}$ hydrogen bonding in the structure of $\left[\mathrm{Cp}_{2}{ }_{2} \mathrm{Mo}_{2}(\mu-\mathrm{O})(\mu-\right.$ $\left.\left.\mathrm{SCH}_{2} \mathrm{CH}_{2} \mathrm{COO}\right)_{2}\right] \cdot \mathrm{HOOCCH} \mathrm{CH}_{2} \mathrm{SSCH}_{2} \mathrm{CH}_{2} \mathrm{COOH}$. 
The presence of the disulfide molecule in the crystal is also revealed by the ${ }^{1} \mathrm{H}$ NMR study. However, an ordinary spectrum does not allow the clear-cut identification of all protons in the organometallic dinuclear species. Each pair of $\mathrm{CH}_{2}$ protons is diastereotopic and yields an $\mathrm{ABCD}$ system for the $\mathrm{CH}_{2} \mathrm{CH}_{2}$ tether, which partially overlaps with the stronger triplets of the free disulfide molecule at $\delta 2.99$ and 2.81. An unambiguous identification of the four mutually coupled protons of the ABCD system was possible by a 2D-COSY experiment (see Supporting Information). The two stronger triplet resonances only show, as expected, coupling cross-peaks with each other, leading to the straightforward identification of the 4 resonances of the ABCD system from the additional cross-peaks.

The title compound was also investigated by cyclic voltammetry. As shown in Figure $4 \mathrm{a}$, the compound undergoes a reversible oxidation wave in $\mathrm{CH}_{2} \mathrm{Cl}_{2}$ solution at $\mathrm{E}_{1 / 2}=0.06 \mathrm{~V}$ vs. ferrocene. This indicates that the mixed-valence $\mathrm{Mo}_{2}{ }^{\mathrm{IV}, \mathrm{V}}$ product enjoys a certain stability. Conversely, the reduction behaviour is less well defined. A major irreversible wave is observed at $\mathrm{E}_{\mathrm{p}, \mathrm{c}}=-1.96 \mathrm{~V}$, with an associated oxidation peak of reduced intensity. This suggests that a chemical process is coupled to the electrochemical reduction. Two less intense reduction waves at less negative potential probably originate from the co-crystallized disulfide by-product. An electrochemical investigation of the related thioglycolate product, $\left[\mathrm{Cp}_{2}{ }_{2} \mathrm{Mo}_{2}(\mu-\mathrm{S})\left(\mu-\mathrm{SCH}_{2} \mathrm{CO}_{2}\right)_{2}\right]$, was not previously carried out [11], therefore we proceeded to examine this behaviour for comparison purposes with the title compound, see Figure $4 \mathrm{~b}$. This compound shows a reversible oxidation at $\mathrm{E}_{1 / 2}=0.32 \mathrm{~V}$ and a reduction at $\mathrm{E}_{\mathrm{p}, \mathrm{c}}=-1.54 \mathrm{~V}$. Negligible electrochemical activity is observed in this case at intermediate potentials, since this sample was recovered as a powder after washing away the disulfide by-product with pentane. The shape of the reduction wave of this compound is similar to that of the related mercaptopropionate compound. Therefore, the thioglycolate derivative also gives a non persistent reduction product. Both waves are shifted to less positive potentials on going from 
the thioglycolato to the mercaptoptopionato derivative $(\Delta=-0.26 \mathrm{~V}$ for the oxidation process and $-0.42 \mathrm{~V}$ for the reduction process). Since the coordination mode of the two mercaptoacids is identical, the effect of the additional $\mathrm{CH}_{2}$ group in the ligand backbone is probably not having a large effect on the redox potentials. The potential shifts are mostly related to the change of the single atom bridge from sulphur to oxygen. The negative shift is consistent with the harder and stronger $\pi$-donating character of the lighter group 16 element, which is then better able to stabilize higher oxidation states (easier oxidation process), whereas the heavier and softer sulphur atom is better able to stabilize lower oxidation states (easier reduction process).

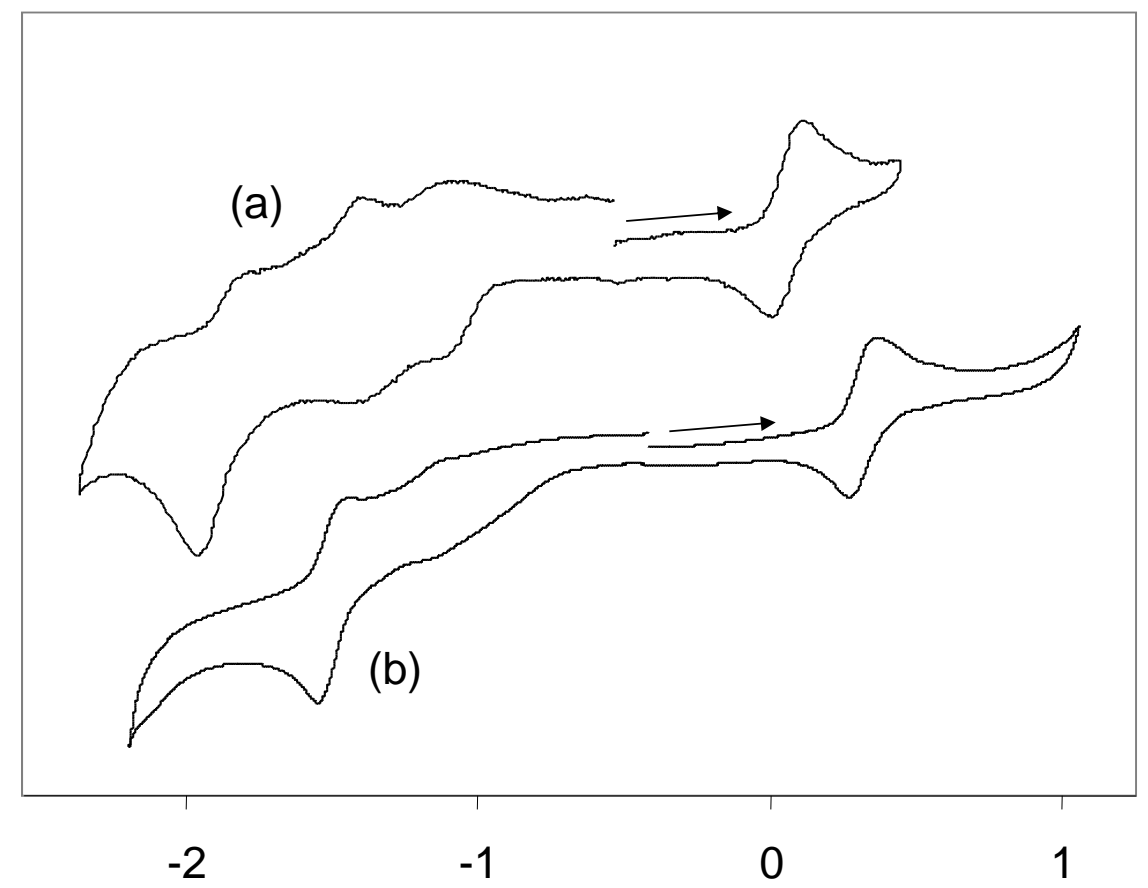

E/V vs. ferrocene

Figure 4. Cyclic voltammetry in $\mathrm{CH}_{2} \mathrm{Cl}_{2}$ solution of : (a) compound $\left[\mathrm{Cp}^{*}{ }_{2} \mathrm{Mo}_{2}(\mu-\mathrm{O})(\mu-\right.$ $\left.\left.\mathrm{SCH}_{2} \mathrm{CH}_{2} \mathrm{CO}_{2}\right)_{2}\right] \cdot\left(\mathrm{HO}_{2} \mathrm{CCH}_{2} \mathrm{CH}_{2} \mathrm{SSCH}_{2} \mathrm{CH}_{2} \mathrm{COOH}\right)$; (b) compound $\left[\mathrm{Cp}_{2}{ }_{2} \mathrm{Mo}_{2}(\mu-\right.$ $\left.\mathrm{S})\left(\mu-\mathrm{SCH}_{2} \mathrm{CO}_{2}\right)_{2}\right]$.

The two compounds were also investigated in a mixed $\mathrm{MeOH}-\mathrm{H}_{2} \mathrm{O}$ solution $(50: 50$ ratio) at various $\mathrm{pH}$ values in the $2-8$ range. For both compounds, the oxidation process is 
$\mathrm{pH}$-independent, whereas the reduction process shifts toward more negative potentials as the $\mathrm{pH}$ increases. A figure showing representative data for the mercaptoacetic complex are given in the Supporting Information. This is consistent with the molecular structure of the two compounds, since the one-electron oxidation product does not have active protons and therefore cannot be deprotonated. Conversely, the one-electron reduction product can accept a proton from the medium, most likely on the single-atom brigde. The half-wave of the $\mathrm{pH}$ independent oxidation process is $0.49 \mathrm{~V}$ vs. ferrocene in $\mathrm{MeOH}-\mathrm{H}_{2} \mathrm{O}$ (vs. $0.32 \mathrm{~V}$ in $\mathrm{CH}_{2} \mathrm{Cl}_{2}$ ) for the sulfido-bridged thioglycolate compound and $0.30 \mathrm{~V}$ (vs. $0.06 \mathrm{~V}$ in $\mathrm{CH}_{2} \mathrm{Cl}_{2}$ ) for the oxo-bridged mercaptopropionate compound. Thus, the negative shift observed for the potentials in $\mathrm{CH}_{2} \mathrm{Cl}_{2}$ on going from the S-bridged to the O-bridged complex is also reproduced in the mixed $\mathrm{MeOH}-\mathrm{H}_{2} \mathrm{O}$ solvent, although the difference is less $(\Delta=-0.19 \mathrm{~V}$ in $\mathrm{MeOH}-\mathrm{H}_{2} \mathrm{O}$, vs. $-0.26 \mathrm{~V}$ in $\mathrm{CH}_{2} \mathrm{Cl}_{2}$ ). Solvation differences in the different solvents, especially for the reduced charged species, are the probable cause of this effect.

The major point of interest in this study is the different outcome of the reactions of $\mathrm{Cp}^{*}{ }_{2} \mathrm{Mo}_{2} \mathrm{O}_{5}$ with two closely related substrates, $\mathrm{HS}\left(\mathrm{CH}_{2}\right)_{\mathrm{x}} \mathrm{COOH}(\mathrm{x}=1$ or 2$)$, to yield two closely related products, $\mathrm{Cp}^{*}{ }_{2} \mathrm{Mo}_{2}(\mu-\mathrm{X})\left[\mu-\mathrm{S}\left(\mathrm{CH}_{2}\right)_{\mathrm{X}} \mathrm{CO}_{2}\right]$, which however surprisingly differ in the nature of the bridging $\mathrm{X}$ ligand: $\mathrm{S}$ for $\mathrm{x}=1$ (previously described) [11] and $\mathrm{O}$ for $\mathrm{x}=2$ (described here for the first time). While we do not currently have sufficient information to outline the intimate details of the reaction mechanism, we note that thioglycolates are more facile substrates than alkyl mercaptans for the hydrodesulfurization process. For instance, $\mathrm{HSCH}_{2} \mathrm{COX}\left(\mathrm{X}=\mathrm{OMe}, \mathrm{OEt}, \mathrm{Me}, \mathrm{NMe}_{2}\right)$ are hydrodesulfurized efficiently and with high selectivities to the corresponding $\mathrm{CH}_{3} \mathrm{COX}$ under $\mathrm{H}_{2}\left(20\right.$ bar) with the $\mathrm{Cp}_{2} \mathrm{Mo}_{2}(\mathrm{CO})_{4}$ catalyst, whereas $\mathrm{HSCH}_{2} \mathrm{CH}_{2} \mathrm{COOMe}$, n-octylmercaptan and thiophenol are much less reactive. Compound $\mathrm{Cp}_{2} \mathrm{Mo}_{2}(\mu-\mathrm{S})_{2}\left(\mu-\mathrm{SCH}_{2} \mathrm{COOEt}\right)_{2}$ was isolated from the catalytic mixture and structurally characterized [35]. It is therefore likely that mercaptoacetic molybdenum 
complexes having suitable coordination geometries and/or oxidation states are more susceptible to C-S bond cleavage than longer-chain analogues. The authors of the above catalytic study formulated the hypothesis that the S-C bond is activated in a bimetallic Mo$\mathrm{SCH}_{2} \mathrm{CO}(\mathrm{X})-\mathrm{Mo}$ intermediate [35]. The same is probably true for out system. Thus, although the products obtained with $\mathrm{HS}\left(\mathrm{CH}_{2}\right)_{\mathrm{x}} \mathrm{COOH}(\mathrm{x}=1$ or 2$)$ are structurally related, they could be formed by quite different mechanisms.

It is highly unlikely that $\mathrm{C}-\mathrm{S}$ bond cleavage for the mercaptoacetic acid reaction occurs after the formation of an oxo-bridged product, because we see no evidence (by ESI MS) for the formation of an oxo-bridged intermediate in the synthesis of the $\mathrm{Cp}^{*}{ }_{2} \mathrm{Mo}_{2}(\mu-\mathrm{S})(\mu-$ $\left.\mathrm{SCH}_{2} \mathrm{CO}_{2}\right)_{2}$ product. In addition, compound $\mathrm{Cp}_{2}{ }_{2} \mathrm{Mo}_{2}(\mu-\mathrm{O})\left(\mu-\mathrm{SCH}_{2} \mathrm{CH}_{2} \mathrm{CO}_{2}\right)_{2}$ does not react with an excess of mercaptoacetic acid under the same conditions that lead to its synthesis (50:50 MeOH- $\mathrm{H}_{2} \mathrm{O}$ mixture, acidified by $\mathrm{CF}_{3} \mathrm{COOH}$, at room temperature). No reaction was detected even after warming the mixture for $1 \mathrm{~h}$ at $100^{\circ} \mathrm{C}$. Conversely, no reaction took place under the same conditions when mixing compound $\mathrm{Cp}^{*}{ }_{2} \mathrm{Mo}_{2}(\mu-\mathrm{S})\left(\mu-\mathrm{SCH}_{2} \mathrm{CO}_{2}\right)_{2}$ with an excess of mercaptopropionic acid.

\section{Conclusion}

The interaction of $\mathrm{Cp}_{2}{ }_{2} \mathrm{Mo}_{2} \mathrm{O}_{5}$ with $\mathrm{HSCH}_{2} \mathrm{CH}_{2} \mathrm{COOH}$ in an aqueous environment at room temperature quite readily leads to reduction to $\mathrm{Mo}^{\mathrm{IV}}$ with incorporation of the doubly deprotonated substrate as a ligand, but contrary to the previously reported process with the closely related $\mathrm{HSCH}_{2} \mathrm{COOH}$ substrate, a C-S bond cleavage does not occur. This difference relates to a previously established more facile hydrodesulfurization of mercaptoacetic acid with respect to mercaptopropionic acid and to simpler alkylthiols. 


\section{Acknowledgements}

We are grateful to the European Commission for funding of this work through the

AQUACHEM Research Training Network (Project $\mathrm{n}^{\circ}$ MRTN-CT-2003-503864).

Supplemental support by a Bosphorus bilateral Programme of Integrated Actions, cosponsored by French Ministry of Foreign Affairs in France and by TUBITAK in Turkey (TBAG-U/142(105T265)) is also gratefully acknowledged. The Israeli group is grateful to the Israel Science foundation for support.

\section{References}

[1] T. Chan, L. Li, Y. Yang, W. Lu, ACS Symp. Ser. 819 (2002) 166.

[2] F. Joó, Acc. Chem. Res. 35 (2002) 738.

[3] I. T. Horvath, Acc. Chem. Res. 35 (2002) 685.

[4] D. Sinou, Topics Curr. Chem. 206 (1999) 41.

[5] D. Sinou, Adv. Synth. Catal. 344 (2002) 221.

[6] G. E. Jaouen, J. Organometal. Chem. (special issue: bioorganometallic chemistry) 589 (1999).

[7] P. Kalck, F. Monteil, Adv. Organometal. Chem. 34 (1992) 219.

[8] B. E. Hanson, Coord. Chem. Rev. 186 (1999) 795.

[9] C. Muller, D. Vos, P. Jutzi, J. Organometal. Chem. 600 (2000) 127.

[10] R. Poli, Chem. Eur. J. 10 (2004) 332.

[11] F. Demirhan, G. Taban, M. Baya, C. Dinoi, J.-C. Daran, R. Poli, J. Organometal. Chem. 691 (2006) 648.

[12] M. Rakowski Dubois, R. C. Haltiwanger, D. J. Miller, G. Glatzmaier, J. Am. Chem. Soc. 101 (1979) 5245.

[13] M. Mckenna, L. L. Wright, D. J. Miller, L. Tanner, R. C. Haltiwanger, M. Rakowski Dubois, J. Am. Chem. Soc. 105 (1983) 5329.

[14] C. J. Casewit, R. C. Haltiwanger, J. Noordik, M. Rakowski Dubois, Organometallics 4 (1985) 119.

[15] J. C. V. Laurie, L. Duncan, R. C. Haltiwanger, R. T. Weberg, M. Rakowski Dubois, J. Am. Chem. Soc. 108 (1986) 6234.

[16] R. T. Weberg, R. C. Haltiwanger, J. C. V. Laurie, M. Rakowski Dubois, J. Am. Chem. Soc. 108 (1986) 6242.

[17] M. B. Gomes De Lima, J. E. Guerchais, R. Mercier, F. Y. Pétillon, Organometallics 5 (1986) 1952.

[18] R. R. Chianelli, Catal. Rev., Sci. Eng. 26 (1984) 361.

[19] P. Grange, Catal. Rev., Sci. Eng. 21 (1980) 135.

[20] H. Topsøe, B. S. Clausen, Catal. Rev., Sci. Eng. 26 (1984) 395.

[21] I. V. Babich, J. A. Moulijn, Fuel 82 (2003) 607.

[22] E. R. Talaty, B. A. Perera, A. L. Gallardo, J. M. Barr, M. J. Van Stipdonk, J. Phys. Chem. A 105 (2001) 8059. 
[23] J.-F. Gal, P.-C. Maria, E. D. Raczynska, J. Mass Spectrom. 36 (2001) 699.

[24] D. Saurenz, F. Demirhan, P. Richard, R. Poli, H. Sitzmann, Eur. J. Inorg. Chem. (2002) 1415.

[25] A. Altomare, M. Burla, M. Camalli, G. Cascarano, C. Giacovazzo, A. Guagliardi, A. Moliterni, G. Polidori, R. Spagna, J. Appl. Cryst. 32 (1999) 115.

[26] G. M. Sheldrick, SHELXL97. Program for Crystal Structure refinement, University of Göttingen, Göttingen, Germany, 1997.

[27] L. J. Farrugia, J. Appl. Crystallogr. 32 (1997) 565.

[28] F. Bottomley, J. Chen, Organometallics 11 (1992) 3404.

[29] F. Abugideiri, G. A. Brewer, J. U. Desai, J. C. Gordon, R. Poli, Inorg. Chem. 33 (1994) 3745.

[30] J. U. Desai, J. C. Gordon, H.-B. Kraatz, V. T. Lee, B. E. Owens-Waltermire, R. Poli, A. L. Rheingold, C. B. White, Inorg. Chem. 33 (1994) 3752.

[31] S. Poder-Guillou, P. Schollhammer, F. Y. Petillon, J. Talarmin, K. W. Muir, P. Baguley, Inorg. Chim. Acta 257 (1997) 153.

[32] F. Abugideiri, J. C. Fettinger, R. Poli, Inorg. Chim. Acta 229 (1995) 445.

[33] M. C. Etter, J. C. Macdonald, J. Bernstein, Acta Cryst. B46 (1990) 256.

[34] J. Bernstein, R. E. Davis, L. Shimoni, N.-L. Chang, Angew. Chem., Int. Ed. Engl. 34 (1995) 1555.

[35] W. Keim, Y. Zhu, E. Herdtweck, W. A. Herrmann, J. Mol. Catal. 58 (1990) 355. 